\title{
EVALUATION OF PERSONNEL MANAGEMENT AT SDN JREBENG KIDUL PROBOLINGGO CITY AND SDN KARENG KIDUL PROBOLINGGO REGENCY
}

\author{
Ribut Prastiwi Sriwijayanti \\ Universitas Panca Marga \\ yanti.rps@gmail.com
}

\begin{abstract}
The general purpose of this study was to review personnel management at SDN Jrebeng Kidul Kota Probolinggo and SDN Kareng Kidul probolinggo. More specifically, the purpose of this research is to describe the components of personnel management, namely recruitment, selection, development, maintenance and empowerment of personnel. This research design is a qualitative approach with this type of evaluation. The research design used is to capture results in the field by means of data collection, compare the results of data collection obtained by standards, provide proposals to improve, improve focus that is not in accordance with the theory, and create an evaluation matrix. One principal from SDN Jrebeng Kidul, one principal from SDN Kareng Kidul, 5 teachers for SDN Jrebeng Kidul and 6 teachers for SDN Kareng Kidul were the subjects of this research. The method of data collection is carried out with in-depth interviews, participating observations, and document studies. Analysis of personnel management work, human resources plan in privately paid teacher recruitment and recruitment process has been good but needs to be improved. Personnel management selection process needs to use multi method of selection. Assessment of work performance, counseling, discipline, training and development of personnel management need to be continuously developed by the leadership of the institution. The maintenance components that need to be improved are compensation, employee relations, employee service, and safety and health. Personnel audits, job satisfaction and career security and health plan also need to be optimized on the usage component. Evaluation of personnel management does need to be continuously optimized regularly and periodically.
\end{abstract}

Keywords: evaluation; personnel management components; primary school.

Abstrak: Tujuan umum penelitian ini adalah mengkaji manajemen personalia di SDN Jrebeng Kidul Kota Probolinggo dan SDN Kareng Kidul Kabupaten Probolinggo. Lebih spesifik, tujuan riset ini adalah mendeskripsikan komponen-komponen manajemen personalia yaitu rekrutmen, seleksi, pengembangan, pemeliharaan dan pemberdayaan personalia. Rancangan riset ini adalah pendekatan kualitatif dengan jenis evaluasi. Desain riset yang digunakan adalah memotret hasil di lapangan dengan cara pengumpulan data, membandingakn hasil pengumpulan data yang diperoleh dengan standar, memberikan usulan guna memperbaiki, menyempurnakan fokus yang belum sesuai dengan teori, dan membuat matriks evaluasi. Satu kepala sekolah dari masing-masing institusi dan 5 guru untuk SDN Jrebeng Kidul dan 6 Guru untuk SDN Kareng Kidul, dijadikan subjek riset ini. Metode pengumpulan data dilakukan dengan wawancara mendalam, pengamatan berperan serta, studi dokumen. Analisa pekerjaan manajemen personalia, perencaan SDM dalam rekrutmen guru privately paid dan proses rekrutmen sudah baik tetapi perlu ditingkatkan. Proses seleksi manajemen personalia perlu menggunakan penggunaan multi metode seleksi. Penilaian prestasi kerja, konseling, disiplin, latihan dan pengembangan manajemen personalia perlu terus dikembangkan oleh pimpinan lembaga. Komponen pemeliharaan yang perlu ditingkatkan adalah pemberian kompensasi, hubungan baik karyawan, pelayanan karyawan, dan keamanan serta kesehatan. Audit personalia, kepuasan kerja dan perencaanan karier keamanan dan kesehatan juga perlu dioptimalkan pada komponen penggunaan. Evaluasi manajemen personalia memang perlu terus dioptimalkan secara rutin dan berkala.

Kata kunci: evaluasi; komponen manajemen personalia; sekolah dasar. 


\section{INTRODUCTION}

Professional institutions require optimal management. The management includes resourced schools. School resources are education personnel (both Civil Servants teacher, privately paid teacher, guards and administrative staff). This personnel management directs every individual in the school to perform their rights and obligations. Developing personnel management, must understand that humans are not inanimate objects because they have feelings. At times they are happy and sometimes they are not. They need not only material, but also recognition and appreciation. Personnel development needs knowledge about psychology, human relationships, customs, and so on. Qualified human resources are a country's priority, effective and productive. Improving the quality of human resources is inseparable from the nation's educational problems. The birth of Law No. 14 of 2005 on Teachers and Lecturers, lead to emerge various new changes in the world of education, especially related to the position, duties, and authority and functional position of teachers.

Personnel are all members of the organization who work for the formulation of organizational objectives. Personnel management components are recruitment, selection, development, empowerment and maintenance of human resources. Law No. 20 of 2003 related to the national education system article (1) states that education personnel are people who are appointed and devote themselves to the implementation of education. Educators are qualified educational personnel such as teachers, lecturers, counselors, students, widyaiswara, tutors, instructors, and facilitators who participate in education. Along with the enactment of Law No. 20 of 2003 above, personnel management becomes a challenge for all schools either public schools or private schools from elementary to college level

Personnel management as a department in charge of recruitment of the workforce plays an important role in carrying out the applicable procedural. Labor admissions procedure is a system that affects school productivity so that carefulness and thoroughness in decision making to receive new workers, must be accountable. If the institution can manage its personnel well, then every personnel can do their job as well (Wardana \& Rulyansah, 2019).

In Indonesia, the implementation of education in elementary schools' rests on several laws and regulations as a juridical basis. As an educational unit, primary school is the most important educational unit of its existence (Rulyansah \& Sholihati, 2018). The large benefits of basic education from all countries, make the government increase investment in the sector from year to year. Education at the basic level is well prepared, both socially-institutionally and functionally academically. Primary school is managed as best as possible so that it becomes a quality primary school (Bafadal, 2003).

The general purpose of this research is to review personnel management in Jrebeng Kidul State Elementary School Probolinggo City and Kareng Kidul State Elementary School Probolinggo Regency. The specific purpose of this research is to describe the components of personnel management, namely personnel recruitment, personnel selection, personnel development, personnel maintenance and personnel empowerment. The question of this research is "how is the evaluation of personnel management in Jrebeng Kidul State Elementary School, Probolinggo City and Kareng Kidul Public Elementary School, Probolinggo Regency, reviewed from the recruitment, selection, development, maintenance and use of personnel management"

\section{METHODS}

This research used a qualitative approach for evaluating the learning implementation in elementary school. The design of the research was to capture the results in the field at SDN Jrebeng Kidul Kota Probolinggo and SDN Kareng Kidul Probolinggo. The data collecting techniques was done by comparing the results of data collection obtained by standards, providing proposals to improve the focus that is not in accordance with the theory, and create an evaluation matrix. 
The research subjects involved were 13 people consisting of 2 principal of institutions (SDN Jrebeng Kidul Kota Probolinggo and SDN Kareng Kidul Probolinggo Regency) and 11 teachers (5 teachers of SDN Jrebeng Kidul Kota Probolinggo and 6 teachers of SDN Kareng Kidul Probolinggo Regency). The determination of the location is based on several considerations. The two schools have carried out personnel management, characteristics of these two schools are different from one and another, the number of civil servant teachers from the two schools is under the appropriate number, recruitment of privately paid teachers, they can be reached by researchers and consideration of time and funds.

Data collection techniques are based on Bogdan \& Biklen (1992) namely in-depth interviews, observational participation and document studies. These three techniques are basic techniques used in research with qualitative approaches. Researchers conducted in-depth interviews with various parties such as principals, vice principals and privately paid teachers. Observation activities participated in obtaining complete and detailed data through careful observation by actively participating in the activities studied. The documents studied were classroom teaching programs, decision letters, letter archives, and photos of school activities related to research focus.

Data analysis techniques used are data reduction, data presentation and verification or recruitment conclusions (Riyanto, 2003). More data can be reduced by selecting the main ones, summarizing and focusing on the important things and according to the theme. The presentation of data is done so that researchers and readers can interpret and interpret the data correctly. Conclusions drawn need to be tested for truth in order to obtain objective and valid conclusions.

\section{RESULTS AND DISCUSSION}

\section{Recruitment}

The success of learning depends on the teacher's ability (Nafiah \& Hartatik, 2017). Therefore, recruitment should indeed be selective. In the management of privately paid teacher personnel from the evaluation results obtained through research at two schools as follows:

\section{Job Analysis}

Based on the findings of research on two public elementary schools in the city and Probolinggo District about the analysis of work shows that in analyzing the work is in accordance with the needs of the school. This is evidenced by the balance between the needs of privately paid teachers in schools and the number of privately paid teachers that exist today

This is in line with the theory by Manullang (2008) namely to be able to carry out selection on prospective employees as best as possible. The first thing, the employers must have a comprehensive information about the position to be filled so that they are able to determine whether a person is able to work in a position or not. Deals with this, it is necessary to know the education, expertise, experience and physical state that match to the need of a position and it can be known by making a job analysis.

\section{Human Resource Planning}

Based on the findings of the study, human resource planning at SDN Jrebeng Kidul Kota Probolinggo and SDN Kareng Kidul Probolinggo regency on human resource planning already has the right steps that follow the recruitment procedures which have been determined by the school

This is in line with the theory by Gomes (2003) that human resource planning is a step taken by management to ensure the right workforce to occupy the right positions, positions and jobs at the right time. This is in order to achieve the goals and various goals that have been set.

Furthermore, Manullang (2008) argues that human resource planning activities include two things, namely labor needs (managerial review, trend ratio analysis, work study, skills and skills 
analysis) and labor supply (analysis of existing resources, waste analysis, assessment of changes in working conditions and attendance as well as estimates of assessment program results).

\section{Recruitment Process}

Based on the findings of the study, the human resource planning at SDN Jrebeng Kidul Kota Probolinggo and SDN Kareng Kidul Probolinggo regency has not been optimal. This is based on several reasons, such as: the ability of the recruitment process is very simple and using only applications that have entered the school. This is because the privately paid teacher recruitment system is adjusted to the school's coffers so that the recruitment process only uses the services of employees in the school.

This is not in agreement with the theory by Heidjrachman \& Husnan (2002) that a good recruitment method can be by using advertising, labor agencies, recommendations from employees who are working, educational institutions, and applications that have entered the school. From the findings of the research and the theory presented above, this can be concluded that the recruitment process determines a teacher who is competent in their field.

\section{Selection}

Based on the findings of the study, the selection at SDN Jrebeng Kidul Kota Probolinggo and SDN Kareng Kidul Probolinggo regency has not been doing appropriately. This is due to the limited formation of the committee in the selection so that in the selection process only the principal and vice principal who handle it

This is not in accordance with the theory put forward by Gomes (2003), namely the selection process is to establish a minimum qualification for a position through the analysis of positions. This relates to certain methods used to measure the qualifications of job applicants. There are 9 methods that are usually used, namely (1) biographical data review, (2) talent or dexterity tests, (3) ability tests, (4) performance tests, (5) references, (6) performance evaluations, (7) interviews, (8) assessment centers, (9) probation

From the two schools as data source, it is acknowledged that schools have never conducted the selection process as one of the indicators in personnel management.

\section{Development}

\section{Work Performance Assessment}

Based on the findings of the study, working performance at SDN Jrebeng Kidul Kota Probolinggo and SDN Kareng Kidul Kabupaten have not been limited. It is found that only SDN Jrebeng Kidul Kota Probolinggo has conducted achievement assessments for privately paid teachers. While SDN Kareng Kidul Probolinggo regency has not been able to carry it out for various reasons that other achievements of work for privately paid teachers alone by using DP3 and privately paid teachers only help teachers who are already civil servants.

It is also certainly not in agreement with the theory presented by Handoko (2003) namely performance appraisal is the process through which organizations evaluate or assess employee performance. The usefulness of work performance assessment can be detailed as performance improvement, compensation settlement, placement decisions, training and development needs, career planning and development, staffing process deviation, informational inaccuracies, job design errors, fair employment opportunities, external challenges

From the findings of research and theories presented above, it can be concluded that the assessment of the work performance of privately paid teachers as one of the standard indicators in the development of personnel management.

\section{Counseling}

Based on the findings of the study, counseling at SDN Jrebeng Kidul Probolinggo and SDN Kareng Kidul Kabupaten has not been optimal. From the two schools as research instruments only SDN Jrebeng Kidul Kota Probolinggo has conducted counseling to all teachers and employees, 
while SDN Kareng Kidul Probolinggo regency has not been able to carry it out thoroughly for various reasons that counseling only takes place around trusted teachers and counselors handled by Islamic teachers

The formulation of counseling is a process of interaction between two individuals, each called a counselor and a client. This is conducted in a professional atmosphere way aiming and serving as a means of facilitating changes in client's behavior.

\section{Discipline}

Based on the findings of the study, the discipline at SDN Jrebeng Kidul Kota Probolinggo and SDN Kareng Kidul Kabupaten has not been optimal. From the two schools, instrument of research shows that there are still many honorary teachers who are late and are absent from class for various reasons such as family reasons, illness and so on. This is not in accordance with the theory put forward by Sastrohadiwiryo (2002) that work discipline can be defined as an attitude of respect, respect, obedience and obedience to the prevailing rules, both written and unwritten rule and able to carry it out and not to avoid sanctions if he violates the duties and authorities given to him. This is also certainly not in line with the vision of both schools, namely making disciplinary as a school culture.

\section{Exercise}

Based on the findings of the study, the development of training for privately paid teachers has been carried out continuously but not optimally, especially in technology training. From two schools as research instruments are all constrained in supporting facilities in the training. This is because of the lack of technological tools owned by both schools, some teachers and other employees still do not master the technological tools and the low enthusiasm and spirit possessed by privately paid teachers to participate in training.

In addition, both schools only use seminar training, workshops on class administration, Musyawarah Guru Mata Pelajaran (MGMP), Kelompok Kinerja Guru (KKG) while conducting class action research, scientific writing has never been done. This is based on several reasons such as honorary teachers at SDN Jrebeng Kidul Kota Probolinggo and SDN Kareng Kidul Probolinggo regency have not understood how to write scientific works, privately paid teachers have not understood the steps of class action research and lack of motivation from the teacher itself in improving professional competence.

This is not in accordance with the theory put forward by Gomes (2003) that training is any attempt to improve the performance of workers in a particular job that is being responsible, or a job that has to do with his work. To be effective, training usually has to be included in learning experience, planned organizational activities, and is designed as an answer to the needs that are identified. Ideally, training should be designed to realize the goals of the organization, which at the same time also realizes the goals of individual workers.

Furthermore, related to technology training, this is also certainly not in agreement with the theory presented by Mulyasa (2007) that the use of technology in education and e-learning (is intended to facilitate and streamline learning activities. Teachers are required to have the ability to use and prepare learning materials in a computer network system that can be accessed by students.

\section{Career Advancement}

Based on the findings of the study, management development for privately paid teachers has been carried out well, so there is no need for improvement. This is in line with the theory put forward by Sikula (1981) that the purpose of personnel development and education is (1) to increase the quantity of output, (2) improve the quality of output, (3) Realize personnel planning, (4) improve work morale, (5) increase income or well-being, (6) improve health and safety, (7) prevent unity, and (8) to develop personnel.

\section{Organization}


Based on the findings of the study, the development of organizations in SDN Jrebeng Kidul Kota Probolinggo and SDN Kareng Kidul Kabupaten Probolinggo has not been optimal. There are still many honorary teachers who are not involved in terms of the organizational structure of the school. More important is the civil servant teacher. This is due to: (1) The existence of fear and lack of confidence in privately paid teachers, (2) The Principal's policy in carrying out the organizational structure is still simple and always only uses one type of leadership. This is not in accordance with the theory put forward by Pidarta (1988) namely creative educational personnel and active participation in organizational development is needed. For these are the ones who are able to maintain the survival of the organization from extinction due to the demands of changing times. In addition, these people are also able to maintain one of the educational missions that is as an agent of renewal of the environment.

\section{Maintenance}

\section{Compensation}

Based on the findings of the study, there are benefits felt by privately paid teachers, that the welfare of teachers is getting better let alone privately paid teachers who are already listed in the database that can meet their daily needs. This is in line with Law No. 14 of 2005 on teachers and lecturers, namely improving the quality of teachers and lecturers, improving the welfare of lecturer teachers and protection of the profession of teachers and lecturers. In addition, compensation is in line with the theory put forward by Nawawi (2005) that compensation for organizations or companies means appreciation to workers who have contributed in realizing their goals, through activities called work.

\section{Employee Relations}

Based on the findings of the study, personnel relationships show a conducive work environment and the creation of cooperation and mutual help to help fellow teachers. This is in line with Sikula (1981) namely the organization's climate is an expansion of the concept of moral work. When the moral of work concerns many attitudes or individuals or groups in the work, then the climate includes practices, traditions and habits of working in the organization.

\section{Employee Service}

Based on the findings of the study, the services at SDN Jrebeng Kidul Kota Probolinggo and SDN Kareng Kidul Probolinggo regency have not been optimal. From the two schools, there are some employee services that are still not be fulfilled, namely each school has not provided a special parking space for teachers, the lack of reference books in schools that can cause high interest in reading for teachers and school facilities such as computers are still very limited

It is also certainly not in agreement with the theory presented by Handoko (2003) that services are activities that normally have to be done by employees themselves in their daily lives. In reality many organizations or companies provide various forms or services in the field of routine life of such employees. Each service program intends to meet a variety of continuous needs. The service activities are recreation programs, cafeterias, housing, scholarships, purchasing facilities, financial counseling and various other services (parking lots, vehicle facilities, scholarships for employees' children, Eid gifts and others).

\section{Safety and Health}

Based on the findings of the research, the safety and health at SDN Jrebeng Kidul Probolinggo and SDN Kareng Kidul Probolinggo regency has not been optimal. From the two schools as research instruments there are some employee services that are still not fulfilled, namely equally do not have a special security officer. This is because it is adjusted to the school's coffers and there is a dual profession between security and janitors.

This fact is certainly not in line with the theory put forward by Megginson (1981), "The term safety is an overall term that can include both safety and health hazards. In the personnel area, however, a distinction is usually made between them. Occupational safety refers to the condition of being safe from suffering or causing-hurt, injury or loss in the workplace. Safety 
hazards are those aspects of the work environment that can cause burns, electrical shock, cuts, bruises, sprains, broken and the loss of limbs, eyesight or hearing. They are often associated with industrial equipment or the physical environment and involve job tasks that require care and training. The harm is usually immediate and sometimes violent. Occupational health refers to the condition ofe being free from physical, mental or emotional disease or pain caused by the work environment that, over a period of time, can create emotional stress or physical disease."

Safety includes two terms of safety risk and health risk. In the field of staffing, the two terms are distinguished. Occupational safety indicates safe or safe conditions from suffering, damage or loss at work. Safety risks are aspects of the work environment that can cause fire, fear of electricity, cuts, bruises, sprains, fractures, loss of body tools, vision and hearing. All of that is often associated with corporate equipment or the physical environment and includes work tasks that require maintenance and exercise. While occupational health that shows a condition that is free from physical, mental, emotional or pain disorders caused by the work environment. Health risks are factors in the work environment that work beyond the specified time period, an environment that can create emotional stress or physical disturbances.

Use

1. Career Planning

Based on the findings of the study, career planning for privately paid teachers has been carried out well at SDN Kareng Kidul Probolinggo regency while at SDN Jrebeng Kidul Probolinggo regency is still not optimal. This is because the school only pay attention on career planning for civil servant teachers only. On the contrary, privately paid teachers are only focused on helping teachers who are civil servants. In addition, privately paid teachers are not included in the data base so that it is only prioritized in the short term.

This fact is certainly not in line with the theory put forward by Irawan (1997) namely career planning is an activity or effort to map the career journey of employees and identify things that can be done to achieve certain career goals. There is a gap between the theory and the findings in the field that show that there is no career planning at the school.

\section{Job Satisfaction}

Based on the findings of the study, there is a positive spirit and attitude in privately paid teachers. This is in line with the theory put forward by Handoko (2003). Job satisfaction is a pleasant or unpleasant emotional state in which employees view their work. Job satisfaction reflects feelings for his work. This is an evident in the employee's positive attitude towards the job and everything encountered in his work environment.

3. Personnel Audit

Based on the findings of the study, the personnel audit for privately paid teachers has been carried out well and sustainably at SDN Kareng Kidul Probolinggo Regency. This is because SDN Jrebeng Kidul Kota Probolinggo has not understood the difference between auditing and supervision of schools and institutions prioritizes civil servant teachers over honorary teachers in personnel audits

This fact is not in line with the theory put forward by Handoko (2003). Personnel audit is evaluating personnel activities conducted in an organization. Such audits may include one department or a whole company. The results provide feedback on personnel functions for operations managers and personnel departments.

\section{CONCLUSIONS}

Job analysis, planning and personnel recruitment process is a component of personnel management recruitment whose implementation has been good but not optimal so it needs to be improved. The head of the institution needs to pay more attention in selecting privately paid teachers by utilizing various selection methods. Assessment of work performance, counseling, 
discipline, privately paid teacher development exercises, management development, and development of personnel management organizations need to receive special attention by institutional leaders. In the components of compensation, compensation, fostering good relations of employees, employee services and security and health of employees still need to be improved equalization. On the other hand, the components of usage, career planning, job satisfaction and personnel auditing have been considered good but need to be improved again

In recruitment, it is expected that privately paid teachers always pay attention to the needs of teachers related to the completeness of school facilities for all teachers to support the improvement of the quality of privately paid teachers. The principal and education office arrange for high school graduate teachers or Madrasah Aliyah to continue their studies at Universitas Terbuka (UT) which is on Sundays. The school should have a more detailed personnel management so that in selecting not only using interview methods, performances and references, but can use other methods such as knowledge tests, talent tests, biographical reviews, performance evaluations and probation. It is necessary to conduct trainings that are useful to improve the quality of teachers in improving the ability and self-development which includes science and technology training, scientific writing training. The government should design a program to distribute aid funds to complete and build existing school facilities.

\section{REFERENCES}

Bafadal, I. (2003). Manajemen Peningkatan Mutu Sekolah Dasar, dari Sentralisasi menuju Desentralisasi. Bumi Aksara.

Bogdan, R. C., \& Biklen, S. K. (1992). Qualitative Research for Education: an Introduction to Theory and Methods. Allyn \& Bacon.

Gomes, F. C. (2003). Manajemen Sumber Daya Manusia. Andi Offset.

Handoko, H. (2003). Manajemen. BPFE.

Heidjrachman, R., \& Husnan, S. (2002). Manajemen Personalia (Edisi IV). BPFE.

Manullang. (2008). Dasar-Dasar Manajemen. Ghalia Indonesia (GI).

Megginson, L. C. (1981). Keselamatan dan Kesehatan Kerja. Penerbit Refika Aditama.

Mulyasa, E. (2007). Standar Kompetensi dan Sertifikasi Guru. PT. Remaja Rosdakarya.

Nafiah, N., \& Hartatik, S. (2017). Peningkatan Kompetensi Guru Dalam Membuat Rpph Melalui Supervisi Klinis Di Paud As-Sajidah Driyorejo Gresik. Education and Human Development Journal, 3(1), 9-18. https://doi.org/10.33086/ehdj.v3i1.84

Nawawi, H. (2005). Manajemen Strategik. Gadjah Mada Pers.

Pidarta, M. (1988). Manajemen Pendidikan Indonesia. PT. Bina Aksara.

Riyanto, Y. (2003). Penelitian Kualitatif. SIC.

Rulyansah, A., \& Sholihati, M. (2018). Pengembangan Modul Berbasis Kecakapan Hidup pada Pelajaran Matematika Sekolah Dasar. MUST: Journal of Mathematics Education, Science and Technology, 3(2), 194-211.

Sastrohadiwiryo, S. (2002). Manajemen Tenaga Kerja Indonesia. Bumi Aksara.

Sikula, A. E. (1981). Training dan Pengembangan Tenaga Kerja. Pustaka Binaman.

Wardana, L. A., \& Rulyansah, A. (2019). Pengembangan Model Ruang Kelas Berbasis Tematik di Sekolah Dasar. Sekolah Dasar: Kajian Teori Dan Praktik Pendidikan, 28(2), 125-134. https://doi.org/10.17977/um009v28i22019p125 